Vivien Li, MBBS

Jack Kane, MBBS

Helen H.L. Chan, MBBS

Anthony J. Hall, MD*

Helmut Butzkueven, $\mathrm{PhD} *$

Neurol Neuroimmunol Neuroinflammation

2014;1:e13; doi: 10.1212/ NXI.0000000000000013

\section{CONTINUING FINGOLIMOD AFTER DEVELOPMENT OF MACULAR EDEMA: A CASE REPORT \\ OPEN}

Fingolimod is the first effective oral agent in widespread use for relapsing-remitting multiple sclerosis (MS), but it can cause macular edema (ME) as an uncommon complication. ME may be mild and asymptomatic, but it can also produce visual impairment. The mechanism of fingolimod-associated ME (FAME) is thought to be through sphingosine-1-phosphate receptor antagonism, affecting endothelial integrity and increasing the risk of microvascular leaks. ${ }^{1}$

Analysis of phase 2 and 3 fingolimod studies found 19 cases of ME out of 2,615 patients (0.7\%). ${ }^{1}$ Thirteen had onset within 4 months of fingolimod commencement, 4 had onset between 4 and 12 months, and 2 had onset after 12 months. Fingolimod was ceased in all cases, with complete resolution of ME in 16 and partial resolution in the remainder. Eleven required treatment with topical anti-inflammatory drugs. Risk factors for FAME include previous uveitis and diabetes.

The most sensitive technique for detecting ME is optical coherence tomography (OCT). Treatments include nonsteroidal anti-inflammatory drugs (NSAIDs), corticosteroids, vascular endothelial growth factor antagonists, laser photocoagulation, and vitreoretinal surgery. ${ }^{1}$ However, all have side effects, including delayed healing, increased bleeding and infection risk, and elevated intraocular pressure.

Case report. A 37-year-old woman with an 18-year history of relapsing-remitting MS began fingolimod in May 2011. She had previously used interferon $\beta$-1a and mitoxantrone, but she experienced severe relapses after mitoxantrone cessation when the maximum cumulative dose was reached. She was antiJC virus positive in serum. She has had one episode of right optic neuritis but no history of uveitis or diabetes.

When fingolimod was commenced, she was wheelchair-bound with an Expanded Disability Status Scale (EDSS) score of 7.5. Best corrected visual acuity was 6/18 (left eye [LE]) and 6/18 ophthalmologic examination was otherwise unremarkable. After 4 months' treatment, she could walk short distances with assistance (EDSS 7). Visual acuity was unchanged. However, OCT (using Stratus OCT [Carl Zeiss Meditec, Inc., Dublin, CA] fast macula thickness protocol) revealed a new left foveal cyst with central foveal thickness of $213 \pm 47 \mu \mathrm{m}$ (LE) (normal: $182 \pm$ $23 \mu \mathrm{m})$ (figure). Fundal examination demonstrated altered foveal light reflexes bilaterally, confirming ME.

Because the patient was neurologically improved and natalizumab was relatively contraindicated, she continued fingolimod with regular ophthalmology reviews. She has not had any treatment for $\mathrm{ME}$ and visual acuity remains unchanged. The degree of ME has fluctuated but has not worsened 25 months after diagnosis. Her current EDSS is 6.5 and she is able to walk 20 meters aided.

Discussion. It is recommended that patients undergo baseline ophthalmologic assessment prior to commencing fingolimod and at 3-4 months. Those with a history of diabetes or uveitis should have more frequent examinations. ${ }^{1}$

There are a small number of case reports of FAME in MS, encompassing 11 eyes in 8 patients. ${ }^{2-6}$ Time to onset of visual symptoms or diagnosis of ME ranged from 5 days to 6 months after starting fingolimod.

Management of FAME varied. Fingolimod was discontinued in 6 of 11 eyes; 4 of these were treated with NSAID eye drops and 2 were untreated. In the other 5 eyes, fingolimod was continued with NSAID eye drops in 4 cases and observation only in 1 case. In all 4 treated eyes in which fingolimod was continued, $\mathrm{ME}$ and visual acuity improved or resolved. Attempts were made, unsuccessfully, to wean therapy in 2 eyes and fingolimod was ultimately ceased. ${ }^{3}$ Anti-inflammatory eye drops were followed by sub-tenon triamcinolone injection in 1 case with resolution of $\mathrm{ME}$, but the patient developed acute intraocular hypertension. ME worsened over 1 month in the 1 eye in which fingolimod was continued without treatment, requiring eventual sub-tenon triamcinolone injection. ${ }^{5}$

In 9 of 11 eyes, macular changes disappeared after 3-32 weeks. However, visual recovery was incomplete in 4 of 9 eyes. In 2 of 11 eyes, some ME was still present at time of report.

Increases in macular volume on OCT have been observed more widely in patients on fingolimod over 5-6 months' follow-up. ${ }^{7}$ Whether this represents a neuroprotective effect or rather a subclinical form of 
Figure Serial optical coherence tomographies (OCTs) of left eye (LE) over time with corresponding central foveal thickness (CFT) measurements of both eyes

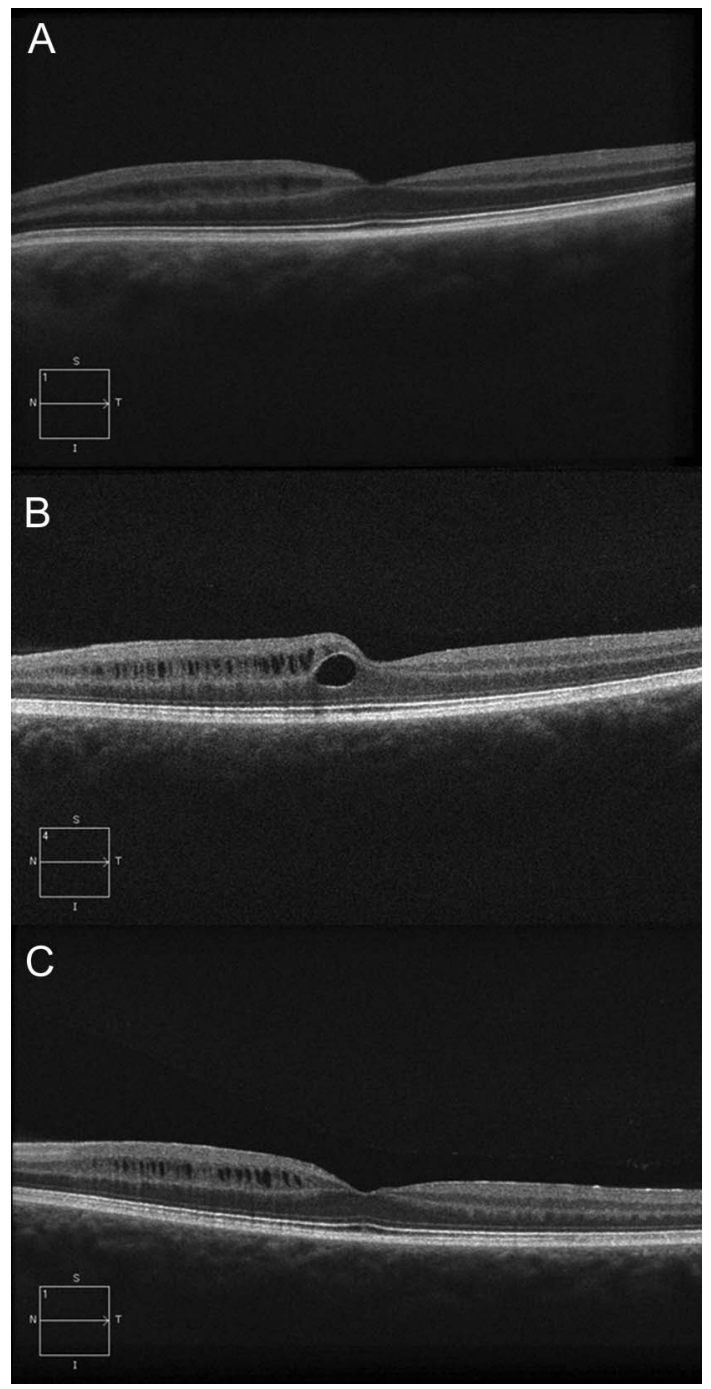

Serial OCTs of LE on (A) October 7, 2011; (B) February 3, 2012; and (C) April 26, 2013. The CFT measurements of both eyes on these dates were (A) $272 \mu \mathrm{m}$ (LE), $262 \mu \mathrm{m}$ (right eye [RE]); (B) $308 \mu \mathrm{m}$ (LE), $258 \mu \mathrm{m}$ (RE); and (C) $259 \mu \mathrm{m}$ (LE), $259 \mu \mathrm{m}$ (RE).

cystoid ME requires further research. This also has implications for interpreting OCT findings in $\mathrm{pa}-$ tients treated with fingolimod.

This case describes a patient continuing fingolimod long-term without additional treatment after FAME onset. Macular changes were first detected after 4 months of treatment, consistent with the time course reported in earlier studies. This report provides Class IV evidence that it may be possible to continue fingolimod in patients with FAME with stable vision and macular changes with very close monitoring, potentially allowing highly selected patients with MS to continue an effective treatment.
* These authors contributed equally to the manuscript.

From the Department of Neurology (V.L., H.H.L.C., H.B.), Royal Melbourne Hospital, Melbourne; University of Melbourne (J.K.); Royal Victorian Eye and Ear Hospital (H.H.L.C.), Melbourne; Department of Surgery (A.J.H.), Monash University (H.B.), Melbourne; Department of Medicine (H.B.), Melbourne Brain Centre (Royal Melbourne Hospital), University of Melbourne; and Department of Neurology (H.B.), Eastern Health, Melbourne, Australia.

Author contributions: Dr. Li was involved in drafting and revising the manuscript. Dr. Kane aided in drafting the manuscript. $D r$. Chan aided in revising the manuscript. Dr. Hall aided in the acquisition of data and revising the manuscript. Dr. Butzkueven aided in the acquisition of data and revising the manuscript.

Study funding: No targeted funding reported.

Disclosure: V. Li, J. Kane, and H. Chan report no disclosures relevant to the manuscript. A. Hall has received research support from the Alfred Hospital Ophthalmology special purposes fund, Monash University. H. Butzkueven has served on scientific advisory boards for MSBase Foundation, Biogen Idec, Novartis (manufacturer of fingolimod for multiple sclerosis), Multiple Sclerosis Research Australia, and SanofiAventis; has received conference travel support from Novartis, Biogen Idec, and Sanofi Aventis; has consulted for Novartis International and Biogen Idec International; holds patents for treatment application of LIF in MS and treatment application of EPHA4 blockade in MS; is on steering committees for trials conducted by Biogen Idec and Novartis; has received research support from Merck Serono, Novartis, University of Melbourne, NHMRC, Australian Research Council, National MS Society, Royal Melbourne Hospital, and Biogen; and is on the editorial boards of Multiple Sclerosis International, Multiple Sclerosis and Related Disorders, and Frontiers in Neuroophthalmology. Go to Neurology.org/nn for full disclosures. The Article Processing Charge was paid by the authors.

This is an open access article distributed under the terms of the Creative Commons Attribution-Noncommercial No Derivative 3.0 License, which permits downloading and sharing the work provided it is properly cited. The work cannot be changed in any way or used commercially.

Received December 13, 2013. Accepted in final form April 21, 2014.

Correspendence to Dr.Butzkueven: butz@unimelb.edu.au

1. Jain N, Bhatti MT. Fingolimod-associated macular edema: incidence, detection, and management. Neurology 2012; 78:672-680.

2. Afshar AR, Fernandes JK, Patel RD, et al. Cystoid macular edema associated with fingolimod use for multiple sclerosis. JAMA Ophthalmol 2013;131:103-107.

3. Chui J, Herkes GK, Chang A. Management of fingolimodassociated macular edema. JAMA Ophthalmol 2013;131: 694-696.

4. Liu L, Cuthbertson F. Early bilateral cystoid macular oedema secondary to fingolimod in multiple sclerosis. Case Rep Med 2012;2012:134636.

5. Minuk A, Belliveau MJ, Almeida DP, Dorrepaal SJ, Gale JS. Fingolimod-associated macular edema: resolution by sub-tenon injection of triamcinolone with continued fingolimod use. JAMA Ophthalmol 2013;131: 802-804.

6. Turaka K, Bryan J. Does fingolimod in multiple sclerosis patients cause macular edema? J Neurol 2013;259:386-388.

7. Nolan R, Gelfand JM, Green AJ. Fingolimod treatment in multiple sclerosis leads to increased macular volume. Neurology 2013;80:139-144. 


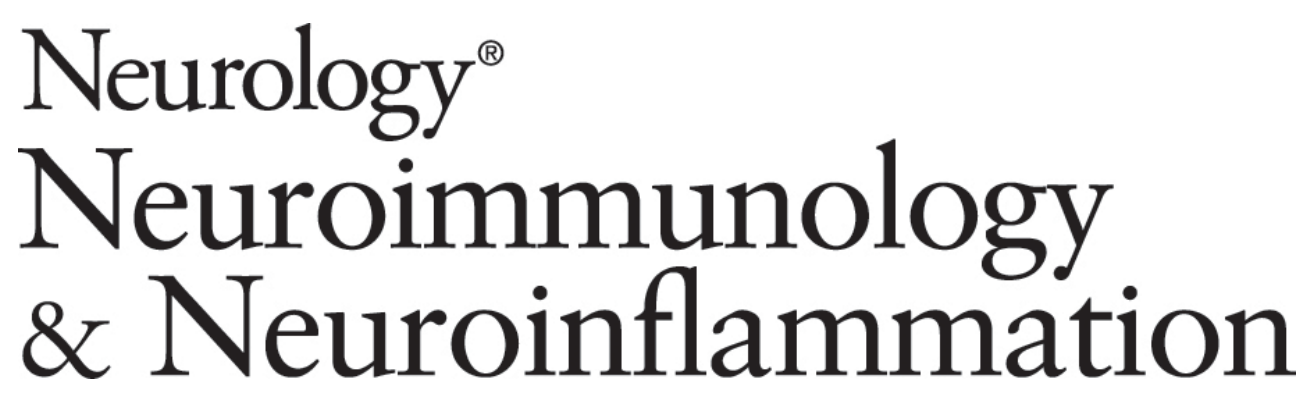

Continuing fingolimod after development of macular edema: A case report

Vivien Li, Jack Kane, Helen H.L. Chan, et al.

Neurol Neuroimmunol Neuroinflamm 2014;1;

DOI 10.1212/NXI.0000000000000013

This information is current as of May 16, 2014

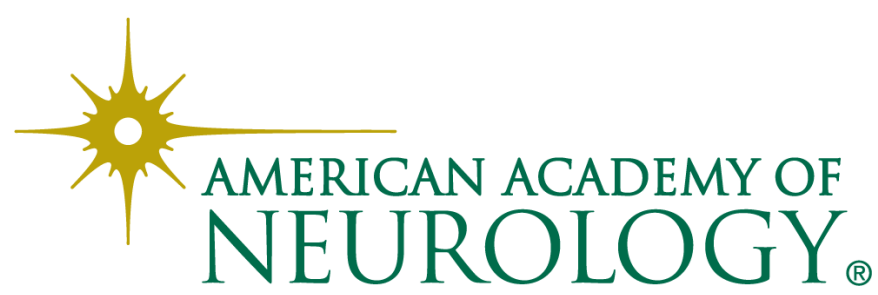




\section{Updated Information \& Services}

References

Citations

Subspecialty Collections

Permissions \& Licensing

Reprints including high resolution figures, can be found at: http://nn.neurology.org/content/1/2/e13.full.html

This article cites 7 articles, 0 of which you can access for free at: http://nn.neurology.org/content/1/2/e13.full.html\#\#ref-list-1

This article has been cited by 1 HighWire-hosted articles: http://nn.neurology.org/content/1/2/e13.full.html\#\#otherarticles

This article, along with others on similar topics, appears in the following collection(s):

All Clinical Neurology

http://nn.neurology.org//cgi/collection/all_clinical_neurology Class IV

http://nn.neurology.org//cgi/collection/class_iv

Multiple sclerosis

http://nn.neurology.org//cgi/collection/multiple_sclerosis

\section{Retina}

http://nn.neurology.org//cgi/collection/retina

Visual loss

http://nn.neurology.org//cgi/collection/visual_loss

Information about reproducing this article in parts (figures,tables) or in its entirety can be found online at:

http://nn.neurology.org/misc/about.xhtml\#permissions

Information about ordering reprints can be found online: http://nn.neurology.org/misc/addir.xhtml\#reprintsus

Neurol Neuroimmunol Neuroinflamm is an official journal of the American Academy of Neurology.

Published since April 2014, it is an open-access, online-only, continuous publication journal. Copyright $\odot$ 2014 American Academy of Neurology. All rights reserved. Online ISSN: 2332-7812.

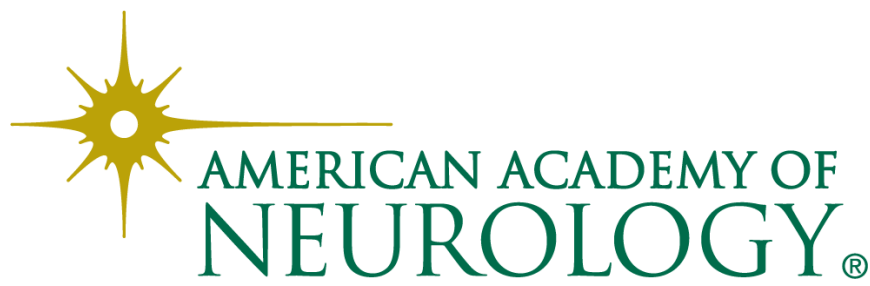

